\title{
Clinicopathological study of breast diseases: A hospital-based study
}

\author{
Ramesh Chavan $^{1}$, Anil Prasad ${ }^{1}$ \\ ${ }^{I}$ Department of Pathology, Jawaharlal Nehru Medical College, Belagavi, India
}

\author{
Keywords: \\ Benign Breast Lesion; \\ Carcinoma; \\ Fibroadenoma; \\ Neoplastic; \\ Nonneoplastic;
}

\begin{abstract}
Background: Breast diseases are more common in women than men. Breasts undergo perpetual physical and physiological transition from puberty till death, which are related to menstruation, pregnancy, and menopause. The aim of this was to classify different types of the breast lesions and conduct its clinicopathological study.
\end{abstract}

Materials and Methods: Breast lesion tissue specimens were collected either as needle biopsy, lumpectomy, or mastectomy. For specimens fixation, 10\% formal saline was used. Tissue was processed into paraffin blocks and stained using hematoxylin and eosin. Data were entered into Microsoft Excel spreadsheets and analyzed using percentages.

Results: Out of 150 patients, $97.3 \%$ were female and $2.7 \%$ were male. Nonneoplastic lesions and neoplastic lesions accounted for $11 \%$ and $89 \%$ of the cases in patients, respectively. Among the nonneoplastic lesions, chronic mastitis (47\%) was most common. Fibroadenoma (76\%) and invasive ductal carcinoma (91\%) was the highest encountered benign and malignant neoplasm, respectively. Maximum (43\%) of benign neoplasm incidence was encountered in the age-group 20-30 years; whereas in malignant neoplasm, it was $40-50$ years (38\%). Out of 150 patients, $55 \%$ were diagnosed with Nottingham grading system grade 2 of breast cancer.

Conclusion: Occurrence of neoplastic lesions in the breasts is comparatively higher than nonneoplastic lesions. Differentiating between benign and malignant lesions would be useful in the management and treatment of patients.

\section{Correspondence:}

Dr. Ramesh Chavan

Department of Pathology,

Jawaharlal Nehru Medical College, Nehru Nagar, Belagavi-590 010 ORICD ID:

Email:drrameshchavan@yahoo.co.in

Reveived : December $10^{\text {th }} 2018$; Accepted : March 14 2019 ; Published : March $29^{\text {th }} 2019$

Citation: Chavan R, Prasad A. Clinicopathological study of breast diseases: A hospital-based study. J Pathol Nep 2019;9:1460-3. DOI 10.3126/jpn.v9i1.21991

Copyright: This is an open-access article distributed under the terms of the Creative Commons Attribution 4.0 International License, which permits unrestricted use, distribution, and reproduction in any medium, provided the original author and source are credited.

\section{INTRODUCTION}

Breast diseases are more common in women than men. Breasts undergo perpetual physical and physiological transition from puberty till death, which are related to menstruation, pregnancy, and menopause. ${ }^{1}$ Breast lesions are a diverse group of lesions that arise in the epithelial or other tissues of the mammary glands and are associated with vascular, inflammatory, or painful pathologies. ${ }^{2}$ Approximately 200,000 cases of breast cancer are diagnosed annually. ${ }^{3}$

Majority of the problem faced by patients with breast disease can be as simple as breast eruption or as threatening 


\begin{tabular}{lcc}
\hline \multicolumn{3}{l}{ Table 1: Distribution according to age group: } \\
\hline Benign lesions & Frequency & $\mathbf{\%}$ \\
\hline Fibroadenoma & 76 & 75.25 \\
\hline Fibroadenosis & 9 & 8.94 \\
Fibrocystic disease & 8 & 7.93 \\
Phyllodes & 4 & 3.96 \\
\hline Lactating adenoma & 3 & 2.97 \\
Duct papilloma & 1 & 0.99 \\
\hline Total & $\mathbf{1 0 1}$ & $\mathbf{1 0 0}$ \\
\hline
\end{tabular}

Table 2: Distribution pattern of malignant lesions of breast

\begin{tabular}{lcc}
\hline Malignant lesion & Frequency & $\mathbf{\%}$ \\
\hline IDC & 29 & 91 \\
\hline $\begin{array}{l}\text { Phyllodes } \\
\text { (malignant) }\end{array}$ & 1 & 3 \\
\hline $\begin{array}{l}\text { Invasive papillary } \\
\text { carcinoma }\end{array}$ & 1 & 3 \\
\hline $\begin{array}{l}\text { Mucinous } \\
\text { carcinoma }\end{array}$ & 1 & 3 \\
\hline Total & $\mathbf{3 2}$ & $\mathbf{1 0 0}$ \\
\hline
\end{tabular}

as cancer. The lumps developed in the breast may result in carcinoma and cause soreness and deformity. ${ }^{4} \mathrm{~A}$ benign form of breast disease is more pervasive than malignant and inflammatory breast disease. Prevalence of benign breast lesions is found frequently in the second decade of life; it reaches the highest point at the fourth and fifth decade of life. ${ }^{5}$ Fibroadenomas constitute most of the cases of benign breast diseases (BBD). Late menopause, first child birth at a younger age, a woman who has never borne a child, and enormous circulating levels of estrogen are the risk factors associated with both benign and malignant breast diseases. ${ }^{6,7}$

It is important for the doctors to recognize the lesion developed so as to categorize them. It is also important to evaluate the possibility of breast cancer and treat the patient accordingly. ${ }^{5}$ In this study, we epitomize the different types of breast lesions - both nonneoplastic and neoplastic, as well as clinical and pathological study of breast lesions.

\section{MATERIALS AND METHODS}

The present study was conducted at the Department of pathology, J. N. Medical college Belgavi (January 2013 to December 2014). Ethical clearance was obtained from the International Ethics Committee on Human Subjects Research, J. N. Medical College, Belagavi. Informed consent was obtained from all the study participants.

The study included 150 patients. Age of patients, clinical features, and other medical details were collected. Specimens (breast biopsy, lumpectomy, or mastectomy) were received from both the sexes of all age-groups. Lesions other than breast lesions in that area were excluded. The breast lesion
Table 3: Distribution pattern of patients under

Nottingham grading system (NGS)

\begin{tabular}{lcc}
\hline NGS & $\begin{array}{c}\text { Number of } \\
\text { patients }\end{array}$ & $\mathbf{\%}$ \\
\hline Grade 1 & 5 & 16 \\
Grade 2 & 17 & 53 \\
Grade 3 & 10 & 31 \\
\hline Total & $\mathbf{3 2}$ & $\mathbf{1 0 0}$ \\
\hline
\end{tabular}

samples were collected in $10 \%$ buffered formal saline and examined for its size, shape, color, and consistency. The presences of lymph nodes and changes in the nipple and skin were noted. Tissue sections were cut $(4-5 \mu \mathrm{m})$ and embedded in paraffin. Hematoxylin, and eosin (H\&E) dye were used for the staining procedure of the samples. Breast biopsy, lumpectomy, and mastectomy were performed according to the standard clinical protocol. ${ }^{8}$ Histological grading of the specimens was performed using NGS. For statistical analysis, data were entered into Microsoft excel sheet and analyzed for percentages.

\section{RESULTS}

A total of 150 patients were studied for more than 24 months. Among all the patients, breast lumps were the most common complaint. Out of 150 patients, 146 patients $(97.3 \%)$ were female and $4(2.7 \%)$ were male.

In this study, $104(69.33 \%)$ patients complained of only breast lumps, 15 patients (10\%) complained of breast lumps associated with pain, 4 (3\%) patients showed breast lump, pain and fever; while 27 (18\%) patients complained of nipple discharge/retraction along with a lump. Nonneoplastic and neoplastic lesions accounted for $11 \%$ and $89 \%$ of total patients, respectively in our findings. Nonneoplastic lesion comprised $47 \%$ of chronic mastitis, $29 \%$ of granulomatous mastitis, $18 \%$ of gynecomastia and $6 \%$ of accessory breast. Among the patients with neoplastic lesions, $76 \%$ and $24 \%$ of patients were diagnosed with benign and malignant lesions, respectively. Fibroadenoma and invasive ductal carcinoma (IDC) were the most commonly found benign and malignant lesion with $75 \%$ and $91 \%$, respectively (Tables 1 and 2). Fibroadenoma was seen to occur in the reproductive age-group between 20 and 30 years, and IDC were seen among the age-group of 40-50 years. During the study, malignant lesions were found to be commonly associated with metastatic lymph node deposits primarily in the axillary group of the lymph nodes, as well as in other agegroup. Out of 29 patients with invasive ductal carcinoma, $15(47 \%)$ patients had axillary lymph node metastasis. One patient (3\%) with metastasis of lymph node was reported in invasive papillary carcinoma.

Nottingham's grading system (NGS) was used for grading breast cancers. A total of 17 (53\%) patients were reported with grade 2 breast cancer. However, 10 (31\%) patients 
were detected with grade 3 breast cancer followed by five (16\%) patients with grade 1 breast cancer (Table 3 ).

\section{DISCUSSION}

The leading cause of death in Asia is due to breast cancer. Female breast malignancy has overtaken uterine cervix cancer. ${ }^{9}$ The constant rise $(0.5-0.2 \%$ per annum $)$ in incidence of breast cancers has been observed all over India across all age-groups, but mainly in age-group less than 45 years. ${ }^{10}$ Benign breast disease has been reported to occur at a higher frequency than malignancy in women. Patients suffering from BBD complain of breast lumps, pain in breast or discharge from the nipple. ${ }^{11}$

The present study was conducted with 150 patients who complained of breast lumps. The study included 97.3\% of male and $4 \%$ female. Aslam et $\mathrm{al}^{12}$ and Vissa Shanti et al. ${ }^{13}$ also reported higher incidence of breast lumps in women than men. Prajapati CL et al. ${ }^{14}$ reported that 550 of 664 patients complained of breast lumps. Out of 664 patients, 458 patients had painless lump, 59 patients had breast lumps associated with pain, and 33 had breast ulcer. Similarly, Aslam et al. ${ }^{12}$ studied 254 cases and reported painless breast lumps in 202 of cases, followed by pain in breast in 38 cases, breast enlargement in three cases, two cases were presented as fever, and complaint of nipple retraction was seen in one case. Our study correlated well with other studies with regard to breast lump presenting as the most common complaint. Neoplastic lesions are found in higher percentage compared to nonneoplastic lesions, these findings are in consonance with the literature..$^{12,15,16}$

Chronic mastitis followed by granulomatous mastitis was frequently observed in nonneoplastic lesions in our findings, whereas past studies reported highest occurrence of breast abscess followed by chronic mastitis. ${ }^{16,17}$ Fibroadenoma forms highly movable, asymptomatic, compact, callus, and frequently palpable mass in the breasts. Their formation can be independent or multilateral, and frequently observed in the early reproductive age of women, which was similar to our results. ${ }^{5}$ Of all benign neoplastic lesions, $50 \%$ were found to be fibroadenoma, this was in similar with the accessible literature on benign breast disease. ${ }^{18,19}$ The prevalence of invasive ductal carcinoma in malignant lesions was reported by Sheikh NA et al. ${ }^{16}$ and Siddiqui MS et al. ${ }^{20}$ Vissa Shanti et al. ${ }^{13}$ reported that $45.8 \%$ of the malignant lesion cases had metastasis in axillary lymph node out of 100 cases, which was found to be the identical with our studies. NGS was used to histologically grade the breast cancer. In our results, $55 \%$ of the patients presented grade 2 and $31 \%$ of patients with grade 3 breast cancer. NGS of histological grading was used in the literature, breast cancer of grade 2 was frequently observed..$^{21,22}$

Breast cancer has made it an endless baffle for the surgeons, oncologists, and pathologists due to the rise in the incidence of breast carcinoma. The incidence of breast cancer deaths and sufferings can be reduced if the patients are timely accessed to early detection. Studies have shown that lack of awareness and late diagnosis are the main barrier in the treatment. This calls for an effective educational programs to create awareness. ${ }^{23}$ Also, very few studies have been oriented towards clinical features, as well as histopathological profiling of breast diseases, which is vital in diagnosis. Thus, this study was performed to establish a groundwork to study various morphological types (nonneoplastic, benign, and malignant) and age distribution in and around Belgavi district.

\section{CONCLUSION}

FNAC is a very useful investigation which provides an accurate and cost-effective preoperative identification of cystic lesion of head and neck. A systematic approach coupled with an awareness of common pitfalls in diagnosis of cystic head and neck lesions can result in correct diagnosis in large number of cases. Sensitivity and specificity of FNAC in diagnosing the malignant lesion was significantly high making it an ideal first line of investigation.

\section{Conflict of interest: None}

\section{REFERENCES}

1. Kumar A, Vohra LS, Bhargava K, Reddy PS. Investigation of Breast lump An evaluation. MJAFI 1999;55:299-302. Crossref

2. Lanyi M. Mammography:Diagnosis and Pathological Analysis, 1st ed. New York: Springer Berlin Heidelberg; 2003. 353p. Crossref

3. Malik M, Salahuddin O, Azhar M, Dilawar O, Irshad H, Sadia SA. Breast diseases; spectrum in Wah cantt; POF hospital experience. Professional Med J 2010;17:366-72.

4. Mehmood A, Ahmed M, Jamal S. Role of cytological grading in the management of breast lump. JCPSP 2003;13:150-52. PMID:12689533

5. Guray M, Sahin AA. Benign breast diseases: classification, diagnosis, and management. Oncologist 2006;11:435-49. Crossref

6. Hislop T, Elwood J. Risk factors of benign breast disease: a 30-year cohort study. Can Med Assoc J 1981;124:283. Crossref

7. Parazzini F, La Vecchia C, Franceschi S, Decarli A, Gallus G, Regallo M, et al. Risk factors for pathologically confirmed benign breast disease. Am J Epidemiol 1984;120:115-22. $\underline{\text { Crossref }}$

8. Rosai J. Appendix E. In: Rosai and Ackerman's Surgical Pathology, 10th ed. Philadelphia: Elsevier Inc; 2011. p. 2589-91.

9. Agarwal G, Pradeep PV, Aggarwal V, Yip CH, Cheung PS. Spectrum of breast cancer in Asian women. World J Surg 2007;31:1031-40. Crossref

10. Murthy NS, Agarwal UK, Chaudhry K, Saxena S. A study on time trends in incidence of breast cancer - Indian scenario. Eur J Cancer Care (Engl) 2007;16:185-6. $\underline{\text { Crossref }}$

11. Dr. Amruthavalli BV, Dr. Srihari V. Clinical Study of Benign Breast Diseases. IOSR-JDMS 2015;14:34-40.

12. Aslam HM, Saleem S, Shaikh HA, Shahid N, Mughal A, Umah R. Clinico- pathological profile of patients with breast diseases. Diagn Pathol 2013;8:77. Crossref

13. Vissa Shanthi, Kashmir Ali, Nandam Mohan Rao. Clinicopathological study of breast lesions in females with assessment of correlation 
between tumor grade and prognostic factors. J Biosci Tech 2011;2:367-78.

14. Prajapati CL, Jegoda RK, Patel UA, Patel J. Breast Lumps in a Teaching Hospital: A 5 Year Study. Natl J Med Res 2014;4:65-7.

15. Al-Thobhani AK, Raja YA, Noman TA, Romaimah MA. Profile of breast lesion among women with positive biopsy findings in Yemen. Eastern Mediterranean Health Journal 2006;12:599-04. $\underline{\text { Crossref }}$

16. Sheikh NA, Farzana C, Ikram-ud-din U, Jawaid AR. Breast diseasespattern at Lumhs, 10 years experience of consecutive referral to public sector medical university at Hyderabad. . Professional Medical J 2012;19.

17. Bagale $\mathrm{P}$, Bagale NV, Bagale S, Ahire N. Clinicopathological study of benign breast diseases. IJHSR 2013;3:47-54.

18. Parajuli S, Koirala U, Khatri R, Acharya L, Suwal A. Histopathological spectrum of Breast lesions. J Nepal Health Res Counc 2011;9:48-51. $\underline{\text { Crossref }}$
19. Olu-Eddo AN, Ugiagbe EE. Benign breast lesions in an African population: A 25-year histopathological review of 1864 cases. Niger Med J 2011;52:211-6. Crossref

20. Siddiqui MS, Kayani N, Gill MS, Pervez S, Muzaffar S, Aziz SA, et al. Breast diseases:a histopathological analysis of 3279 cases at a tertiary care center in Pakistan. J Pak Med Assoc 2003;53:94-7. Crossref

21. Sidoni A, Bellezza G, Cavaliere A, Sordo RE, Scheibel M, Bucciarelli E. Prognostic indexes in breast cancer: comparision of the Nottigham and Adelaide indexes. The Breast 2004;13:23-7. Crossref

22. Elston CW, Ellis IO. Pathological prognostic factors in breast cancer. The value of histological grade in breast cancer: experience from a large study with long-term follow-up. Histopathology 1991;19:40310. $\underline{\text { Crossref }}$

23. Kadam YR, Quraishi SR, Dhoble RV, Sawant MR, Gore AD. Barriers for Early Detection of Cancer Amongst Urban Indian Women: A Cross Sectional Study. Iran J Cancer Prev 2016;9:e3900. Crossref 